\title{
MAJOR STONE FOREST, LITOMORPHOGENESIS AND DEVELOPMNET OF TYPICAL SHILIN (YUNNAN, CHINA)
}

\author{
OSREDNJI KAMNITI GOZD; KAMNINA, SKALNI RELIEF \\ IN RAZVOJ ZNAČILNEGA ŠILINA (JUNAN, KITAJSKA)
}

\author{
Martin KNEZ ${ }^{1,3}$, Hong LIU $^{2,3}$ \& Tadej SLABE ${ }^{1,3}$
}

\begin{abstract}
UDC 551.435.8(513.21)

Martin Knez, Hong Liu \& Tadej Slabe: Major stone forest, litomorphogenesis and development of typical shilin (Yunnan, China)

Major stone forest excellently reveals most characteristics of the formation of the various stone forests. The relatively thick stratification and evenly composed rock clearly display the development of stone forests from subsoil karren. This is evident from the shape of individual parts of the stone forest and the shape and rock relief of pillars that comprise the forest. It is the most typical example of development of karren from subsoil to rain and vegetation exposed stone forest. With it we can compare stone forests shaped on different rock and geomorphological and hydrological conditions. Type of rock is clearly reflected in the intensity of corrosion and erosion and with it in the formation and morphological appearance of individual stone pillars and larger blocks of rock. The rock relief on the pillars in stone forests reveals the interwoven traces of the original shaping of the rock below soil and sediment, of the lowering of the level of soil and sediment, and of the younger but distinct transformation of pillars by rainwater, which naturally dominates on the tops. The exceptional character and picturesqueness of this karst phenomenon is the reason for the successful development of the stone forest as an international tourist attraction that was deservedly placed on the UNESCO world heritage list.

Keywords: stone forest - shilin, litomorfogenesis, rock relief, Yunnan, China.
\end{abstract}

\author{
Izvleček \\ UDK 551.435.8(513.21) \\ Martin Knez, Hong Liu \& Tadej Slabe: Osrednji kamniti gozd; \\ kamnina, skalni relief in razvoj značilnega šilina (Junan, Ki- \\ tajska)
}

Osrednji del kamnitih gozdov - šilina, nam odlično razkriva večino značilnosti oblikovanja različnih kamnitih gozdov. Na razmeroma debelo plastoviti in enakomerno sestavljeni kamnini je jasno zapisan razvoj kamnitih gozdov iz podtalnih škrapelj. O tem pričajo oblika posameznih delov kamnitega gozda, oblika stebrov, ki ga sestavljajo in njihov skalni relief. Osrednji kamniti gozd je najbolj tipični primer razvoja tovrstnih kamnitih gozdov. Z njim lahko primerjamo kamnite gozdove, oblikovane na različnih kamninah in v različnih geomorfoloških ter hidroloških razmerah. Tip kamnine se jasno odraža v intenzivnosti korozije in erozije ter obliki kamnitih stebrov. V skalnem reliefu stebrov so prepletene sledi prvotnega oblikovanja skale pod prstjo in naplavino, znaki nižanja nivoja le teh in mlajšega, a izrazitega preoblikovanja stebrov z deževnico, ki seveda prevladujejo na vrhovih. Izjemnost in slikovitost kraškega pojava je pogoj za uspešen razvoj kamnitega gozda v mednarodno turistično znamenitost in zato si je pridobil tudi zasluženo mesto na UNESCOvi listi naravnih zakladov.

Ključne besede: kamniti gozd, kamnina, skalni relief, razvoj, Junan, Kitajska.

\footnotetext{
${ }^{1}$ Karst Research Institute, Scientific Research Centre of the Slovenian Academy of Sciences and Arts, Titov trg 2, SI-6230 Postojna, Slovenia, e-mails: knez@zrc-sazu.si,slabe@zrc-sazu.si

${ }^{2}$ Yunnan Institute of Geography, Yunnan University, Xuefu rd. 20, CN-650223 Kunming, Yunnan, P.R.China, e-mail: hongliu@yni.edu.cn

${ }^{3}$ Yunnan International Karst Environmental Laboratory, Xueyun rd. 5, CN-650223, Kunming, China, e-mails: knez@zrc-sazu.si, hongliu@yni.edu.cn, slabe@zrc-sazu.si
}

Received/Prejeto: 1.9.2012 


\section{INTRODUCTION}

Mayor stone forest is the typical and referendar example of development of karren from subsoil to rain and vegetation exposed stone forest, shaped in different rock. With it is possible to compare also different types of stone forest in this famous area, which is proved also by previous complex researches. So, the text brings fundamental description of litomorphogenesis and development and represents base for further study and understanding of different types of stone forests. A number of discussions (Habič 1980, Chen et al. 1986, Ford et al. 1997, Kogovšek 1998, Lin 1997, Salomon 1997, Song 1986, Sweeting 1995, Yuan 1991, Yu \& Yang 1997, Zhang 1997) have been published on stone forests and their shape, formation, and development. The findings of complex research on its individual parts have also been presented by the authors of this contribution (Knez 1997, Knez \& Slabe 2001a, 2001 b, 2002, 2006). It was uncovered the unique formation of individual parts of the stone forest on dif- ferent bedrock that displays diverse faulting, different thickness of its strata, and different composition. In the course of research laboratory tests with plaster were also conducted (Slabe 2005).

The central part of the Major stone forest excellently reveals most characteristics of the formation of the various stone forests distributed over $350 \mathrm{~km}^{2}$ (http://en.chinastoneforest.com/). The relatively thick stratification and evenly composed rock clearly display the development of stone forests from subsoil karren. This is evident from the shape of individual parts of the stone forest and the shape and rock relief of pillars that comprise the forest.

The exceptional character and picturesqueness of this karst phenomenon is the reason for the successful development of the stone forest as an international tourist attraction that was deservedly placed on the UNESCO world heritage list.

\section{SHAPE OF STONE FOREST AND STONE PILLARS}

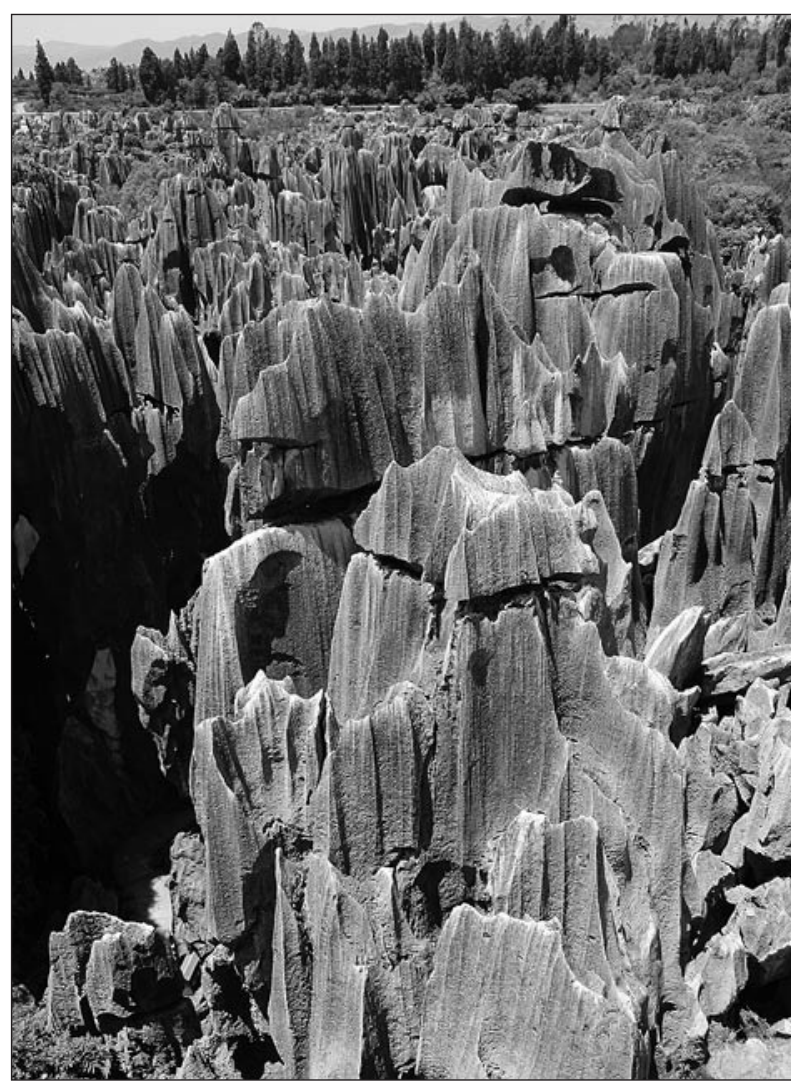

Fig. 1: Stone forest from the top. (Photo: M. Knez)
The central part of the forest (Figs. 1,2) is located in a valley system at 1625-1875 meters above sea level. Most $(70-80 \%)$ of the annual $936.5 \mathrm{~mm}$ of rain falls between June and October (Chen et al. 1986). After abundant precipitation, the water table found just below the surface rises by ten meters. The average temperature is $16.3^{\circ} \mathrm{C}$ and oscillates between $-2^{\circ}$ and $39^{\circ} \mathrm{C}$. The tallest pillars are found in the central part of the valley system where surface waters run into the underground, and there is more sediment in the fringe areas of the stone forest (Sweeting 1995, 125). Habič $(1980,110)$ uses the term "shallow karst" for it. In the lower part of the forest, water also flows on the surface.

The pillars (Fig. 3) are up to 35 meters high. In the central part they usually stand close to each other and the cracks between them are usually 1 to 5 meters wide, while in the wider surrounding areas solitude pillars are also common. They are therefore the remains of carbonate rock between fissures and are correspondingly shaped. Their cross sections are square and triangular as well as oblong and narrow. Dense fissuring of the rock resulted in smaller cross sections of pillars. The pillars composed of thinner and fissured strata in their lower sections are mushroom-like and as a rule display conical tops at the same level. The pillars that were undercut below the ground have relatively horizontal tops that are somewhat more blocky with larger surface areas. 


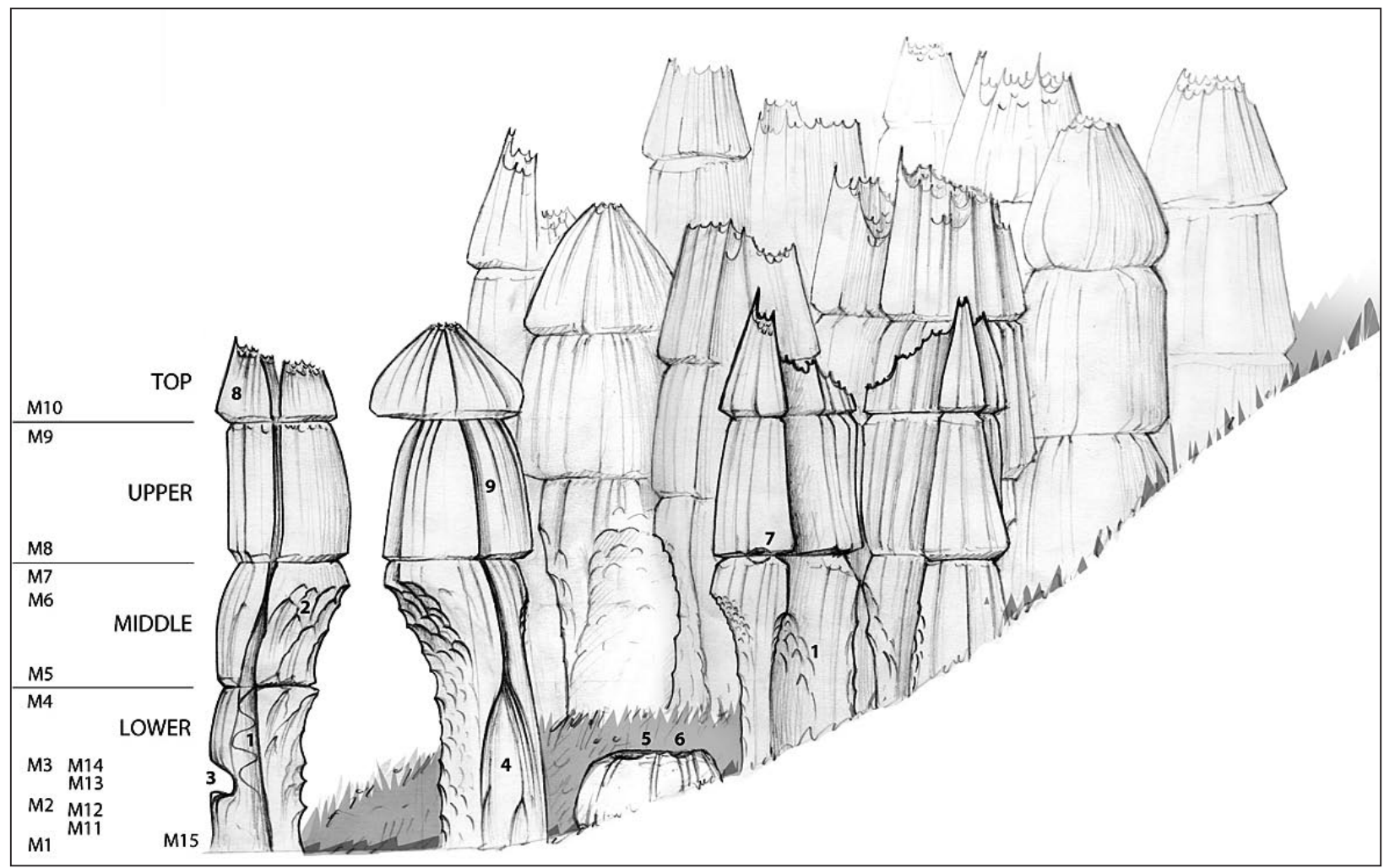

Fig. 2: Cross-section of the Major stone forest with stratigraphical and rock features. (Drawn by: T. Korošec)

1. subsoil channel, 2. subsoil scallops, 3. subsoil notch, 4. subsoil half-bell, 5. subsoil cup, 6. subsoil channel, 7. subsoil tube, 8. rain flutes, 9. channels.

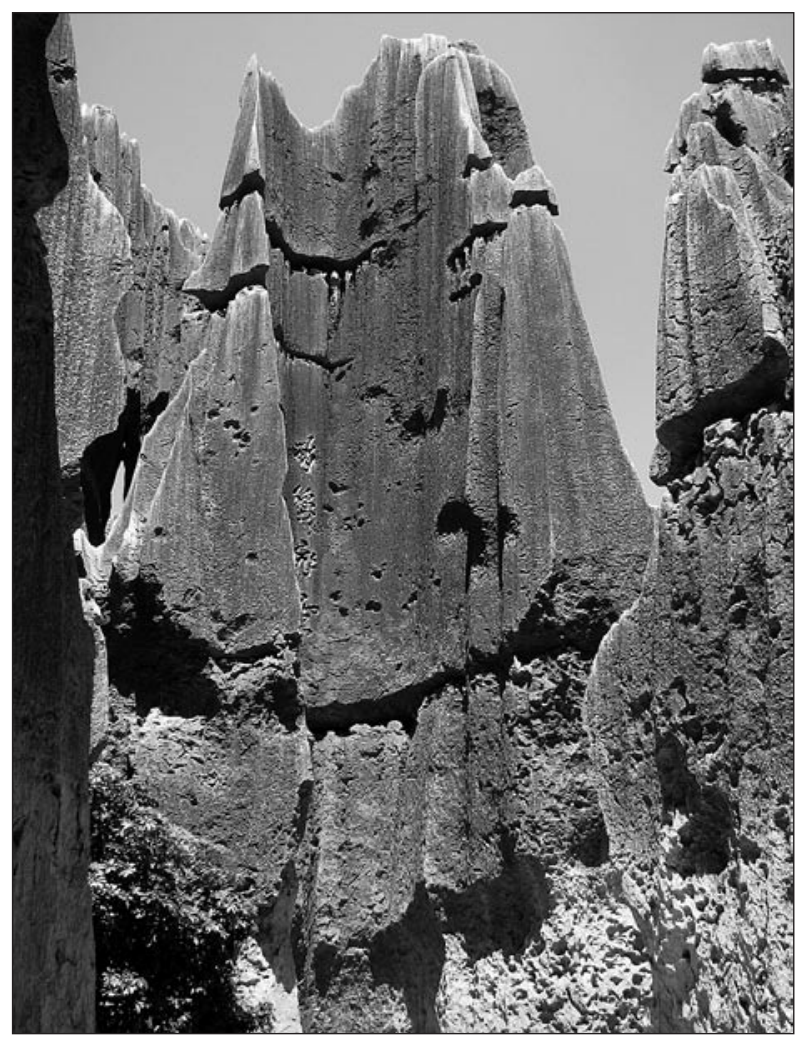

The pillars are also dissected along bedding planes and along long-term levels of sediment and soil. The notches along bedding planes are often jagged, which reflects stylolithization of the rock. Conical and blade-like pillars with sharp tops and ridges dominate. Dzulinski, Gil, and Rudnicki $(1988,8)$ conducted laboratory tests of karren formation on plaster and established that pillars acquire pyramid shapes when the fissures between them become wider. This type of subsoil karren and small stone forest formation was confirmed by laboratory tests on plaster (Slabe 2005). The vertical or even overhanging walls of such pillars are mostly the consequence of accelerated subsoil corrosion of the rock beneath sediment and soil. Individual pillars became perforated under the sediment. Sharp tops were shaped by rainwater. Their straight lines formed along distinct bedding planes. The purer the limestone is, the sharper the shapes of pillars are and the action of rainwater carves new and distinct rock forms across the original subsoil rock relief.

Fig. 3: The pillars are up to 35 meters high. (Photo: M. Knez) 


\section{LITHOSTRATIGRAPHIC AND CALCIMETRIC PROPERTIES OF ROCK}

From the structural and textural viewpoint, the carbonate rock in the Major stone forest, which spreads over $11 \mathrm{~km}^{2}$ (Salomon 1997), is relatively uniform, with the exception of a few shorter sections. The rock is thickly stratified and contains numerous stylolites, and the bedding planes (Fig. 4) are mostly clearly ex-

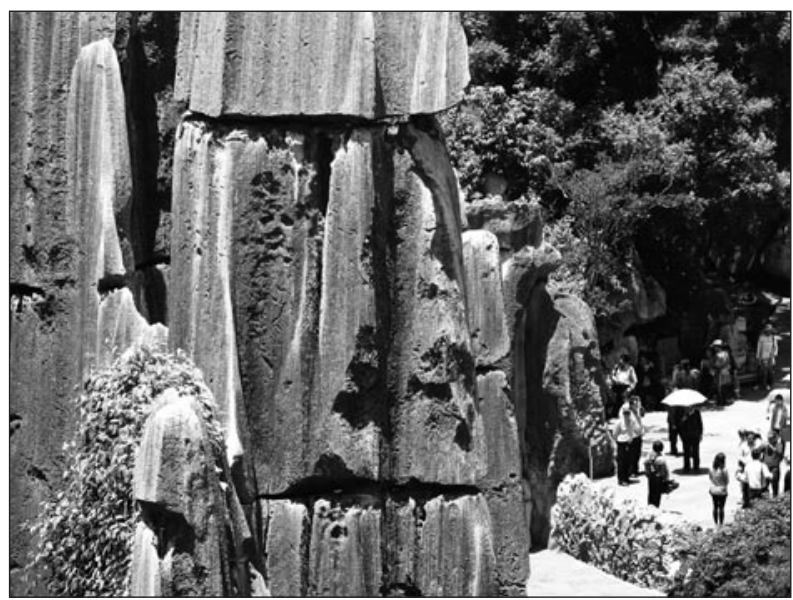

Fig. 4: The rock is thickly stratified, bedding planes are well expressed. (Photo: M. Knez)

pressed and widened by corrosion on the outer side of the rock (Knez 1996, 1997, 1998). All the samples indicate that the 260-million-year-old Lower Permian rock (Maokou formation) was heavily altered diagenetically. Although undamaged by tectonic action, fossil remains are mostly unidentifiable. The dip of the strata, which is mostly around $5^{\circ}$ and seldom larger than $10^{\circ}$, indicates minor regional shifts. At the same time, the results of microscopic observations show that the observed dip of the strata today most probably reflects only a relatively short phase of the tilting of the terrain and that the blocks of rock were only slightly damaged. Nevertheless, the rock contains numerous tiny fissures filled with calcite along which there are no visible shifts. The purity and recrystallization of the carbonate bedrock sometimes make it difficult to identify calcite veins even macroscopically. The regionally extensive gentle anticlinal rising of the rock occurred in a number of phases and periods. Other researchers have also noted that the deformation of the Permian rock was not a single event (cf. Yuan 1991).

The geological description of the carbonate pillars is divided into four sections divided by most expressed bedding planes: lower, middle, upper, and top (Fig. 2). The total height of the studied geological profile (rock pillar) is 37 meters.

\section{MATERIAL AND METHODS}

Several tens of rock samples have been taken from the profile in vertical direction from the bottom to the top. Samples have been taken to Slovenia where thin sections have been made. Thin sections have been researched under the polarizing petrographic microscope by transmitted light. Several samples have been calcimetricaly researched on $\mathrm{CaO}, \mathrm{MgO}$ and total carbonate in chemical laboratory by dissolving of carbonate.

Field research of rock relief is supported by laboratory experiments with plaster of Paris.

\section{LOWER SECTION OF THE PILLAR}

The lower section of the pillar (Fig. 2) is seven meters thick. The lower part of this section, the base of the stone pillar, is composed of biopelmicrite to biopelmicrosparite limestone of the wackestone type. Between the allochems, tiny particles of various bioclasts dominate: uniserial, biserial, and fusulinid foraminifera, mollusks, gastropods, and other unidentifiable organisms. Single whole or fractured fusulinid foraminifera are characteristic of limestone of the Maokou formation. In places the bioclasts show traces of bioturbation. The larger gastropods measure up to $7 \mathrm{~mm}$ in diameter. Individual smaller plasticlasts most frequently appear among intraclasts. The types of porosity include mostly moldic and shelter porosities. There are no calcite veins but frequent secondary porosity can be observed. The rock contains about $20 \%$ of fossil remains, up to $10 \%$ of pellets and pelletoids, and less than $1 \%$ of fusulinid foraminifera (whole or fragmented). Among directly precipitated calcite (orthochemical component) druzy mosaic calcite dominates, filling the interior of still undamaged and well preserved larger fossils, replacing mollusk shells, and filling individual cavities. The calcite forms mostly xenotopic structures. The lower sides of segments of larger fossils (e.g., fusulinid foraminifera) are heavily damaged and show signs of endolithization. Micritized intraclasts often contain voids filled with mosaic coarse crystalline calcite. The geopetal filling of fenestrae with internal sediment below and coarse crystalline sparite above outside the clasts is also characteristic for this section of the geological profile. Given the position of coarse crystalline calcite in the fenestrae, there is no doubt that the strata lie in normal position.

Pelbiomicrosparite to pelbiosparite limestone of the grainstone type is found one meter above the ground or one meter above the current lowest point of uncovered stone. No intraclasts were observed in this part of the geological profile. The biogenic component is represented mostly by fragments of various fossil remains. Larger 
fragments of thick-shelled mollusks are an exception. Between the allochems, an orthochemical component (sparite) is present in the form of granular cement. The limestone is very homogeneous and compact, and calcite veins are not visible.

Three meters above the bottom of the profile the lithological properties of the limestone change significantly. From pelsparite it transforms into biointramicrite limestone of the wackestone to packstone type. Bioclasts in slightly recrystallized rock dominate strongly, occupying some $35 \%$ to $40 \%$ of the volume. The rock displays a clear grain orientation with its longer axis parallel to the stratification.

Five meters above the bottom of the profile there is biomicrite type limestone without identifiable fossil material. Sparite fields of granular calcite are stratified in levels parallel to the stratification.

Pelsparite limestone is observed immediately below the top of the section. Pellets are the dominant allochem component, occupying around $90 \%$ of the volume of the rock.

\section{MIDDLE SECTION OF THE PILLAR}

From the lithological viewpoint, the middle section (Fig. 2) as a whole (separated from the lower section by a bedding plane) has a much more uniform composition. It should be noted that the border area with the lower section or the area above and below the bedding plane separating the two sections is composed of limestone with the same qualities. The middle section is 13 meters thick.

Pelsparite limestone is found at the bottom of the middle section, just as it is in the top of the lower section. They differ primarily in the degree to which the cement has been washed away.

In the central part of the section it is possible to trace a belt of chert nodules that is several meters wide. All the cherts have a characteristic zone structure. On the outside there are darker and lighter belts, the latter of which are wider. The narrower and darker belts contain a considerable amount of the carbonate component. This is most probably due to the silification of the carbonate component. Numerous carbonate inclusions occur in the belts of silificated rock.

The upper part of this section is composed of slightly washed pelbiointra micrite of the wackestone type. The rock is diagenetically altered to such a degree that many original forms and properties can no longer be clearly identified.

Pellets and pelletoids dominate among the allochems; there are a few fragments of various bioclasts: uniserial, foraminifera, mollusks, and other unidentifiable organisms. In places, the bioclasts display traces of bioturbation. It is highly possible that individual smaller plasticlasts also occur among the intraclasts.

Druzy mosaic calcite that fills the interior of still undamaged and well preserved larger fossils, replaces mollusk shells, and fills individual cavities and fissures is the dominant orthochemical component. Here, the calcite forms mostly xenotopic structures.

\section{UPPER SECTION OF THE PILLAR}

The upper section (separated from the middle section by a bedding plane) is monotone from the lithological viewpoint and shows no substantial differences relative to the rock in the section below it (Fig. 2). This section is 13 meters thick.

The lower part of this section has primarily the same qualities as the rock in the top part of the middle section. The most distinct difference is in the orthochemical component where generally smaller grains of micrite calcite have been identified.

In the top part of the section, individual non-transparent minerals up to $0.23 \mathrm{~mm}$ in size were observed along with individual euhedral calcite grains.

\section{TOP SECTION OF THE PILLAR}

Due to conical peaks that are most vulnerable to atmospheric influence, the thickness of the top section (Fig. 2) varies from three to five meters.

The carbonate sedimentation in this part of the geological column has not changed significantly. The top section or the top of the stone pillar is composed of biopelmicrite limestone of the wackestone type.

Among the allochems, fragments of various bioclasts dominate that are difficult to identify due to moderate recrystallization: a variety of foraminifera and fusulinid foraminifera, mollusks, gastropods, and other organisms. In places, the bioclasts show traces of bioturbation.

Mosaic calcite fills the interior of undamaged and well preserved fossils, replaces mollusk shells, and fills individual cavities.

\section{CALCIMETRIC ANALYSIS}

The calcimetric analyses of samples show a high content of total carbonate with the exception of the area along a bedding plane between the lower and middle sections (Tab. 1). The greater part of the lower section of limestone is very pure, with a total carbonate value reaching almost $98 \%$ and an average of 3\% insoluble residue. It is interesting that sample M4, taken immediately below the bedding plane at the top of the lower section, contains considerably less total carbonate and a high value of insoluble residue (40\%). The sample taken just above the bedding plane at the lowest part of the middle sec- 
Tab. 1: Calcimetric analyses of rock samples.

\begin{tabular}{l|r|r|r|r|r|r|r}
\hline Sample & \multicolumn{1}{l|}{ CaO } & MgO & Calcite & Dolomite & Total carbonate & CaO/MgO & Insoluble residue \\
\hline & $\%$ & $\%$ & $\%$ & $\%$ & $\%$ & $\%$ & $\%$ \\
\hline M1 & 54.40 & 0.40 & 96.09 & 1.84 & 97.93 & 136.00 & 2.07 \\
\hline M2 & 54.40 & 0.40 & 96.09 & 1.84 & 97.93 & 136.00 & 2.07 \\
\hline M3 & 53.28 & 0.20 & 94.59 & 0.92 & 95.51 & 266.40 & 4.49 \\
\hline M4 & 33.09 & 0.40 & 58.06 & 1.84 & 59.90 & 82.73 & 40.10 \\
\hline M5 & 27.12 & 0.20 & 47.88 & 0.92 & 48.80 & 135.60 & 51.20 \\
\hline M6 & 54.40 & 0.40 & 96.09 & 1.84 & 97.93 & 136.00 & 2.07 \\
\hline M7 & 54.96 & 0.14 & 97.46 & 0.92 & 98.38 & 392.57 & 1.62 \\
\hline M8 & 54.40 & 0.40 & 96.09 & 1.84 & 97.93 & 136.00 & 2.07 \\
\hline M10 & 54.40 & 0.40 & 96.09 & 1.84 & 97.93 & 136.00 & 2.07 \\
\hline M11 & 53.84 & 0.40 & 95.09 & 1.84 & 96.93 & 134.60 & 3.07 \\
\hline M12 & 54.68 & 0.65 & 92.80 & 3.14 & 95.94 & 81.52 & 4.06 \\
\hline M13 & 55.24 & 0.40 & 96.61 & 2.77 & 99.38 & 91.13 & 0.62 \\
\hline M14 & 54.12 & 0.60 & 95.56 & 2.77 & 98.33 & 90.20 & 0.57 \\
\hline M15 & 0.28 & 0.20 & 0.00 & 0.92 & 0.92 & 1.40 & 1.67 \\
\hline & & & & & & & 99.08 \\
\hline
\end{tabular}

tion also has a very low carbonate content and more than $50 \%$ of insoluble residue, which means it no longer ranks among the carbonates (!). Toward the top of the stone pillar, the total carbonate content as well as the contents of $\mathrm{MgO}$ (with the exception of sample M7) and $\mathrm{CaO}$ do not change considerably. Samples M11 and M12 or M13 and M14 respectively lie just below or just above two more expressed bedding planes in the lower section (Figs. 1,2). Compared to the exceptional uniformity of carbonate rock in the upper and top sections (samples M8 to M10), the pairs of samples along the selected bedding planes show characteristic differences in their chemical components. Sample M15 is a sample of the basalt rock that is in contact with carbonates throughout the forest.

Several Chinese researchers arrived at similar general figures for $\mathrm{CaO}$ and $\mathrm{MgO}$ content in the Maokou formation. The $\mathrm{CaO}$ content found by Lin (1997) for the Maokou formation in the Shilin stone forest totaled $54.73 \%$. His value for $\mathrm{MgO}$, however, is one fourth lower than the value determined. Song and Li (1997) found a slightly higher CaO content. They cite $56.12 \%$ of $\mathrm{CaO}$ in the rock, which is several percentage points higher than the value presented in this article, while the value of $\mathrm{MgO}$ is some ten times lower. The value of $\mathrm{CaO}$ stated by $\mathrm{Yu}$ and Yang (1997) is several percentage points lower than ours, while their value for $\mathrm{MgO}$ is around ten times higher. The same authors (1997) also state insoluble residue contents that are between five and ten times smaller than those found in our samples.

\section{ROCK RELIEF OF STONE FORESTS}

The rock forms that comprise the exceptionally well developed rock relief of the stone pillars can be divided into subsoil rock forms, rock forms carved by rainwater, and composite rock forms. A small proportion of the rock forms develop under vegetation. Composite rock forms are subsoil rock forms reshaped by rainwater; occasionally, both factors contribute to their formation.

\section{SUBSOIL ROCK FORMS}

In the shaping of rock below the soil, the influence of water that becomes enriched by $\mathrm{CO}_{2}$ as it percolates through the soil is significant. This influence, however, usually diminishes after only two to three meters. It was observed that in some places the influence of water percolating along the contact of rock and soil reaches deeper into the soil depending on its permeability. Kogovšek (1998, 74) established that water percolating through soil and cave ceilings has higher hardness values than rainwater, confirming the influence of soil on water. Hantoon (1997, 311) divided the percolation trough epikarst into that at the contact of sediment and rock, percolation through rock, and percolation through sediment, which due to its clay content is small. According to Hantoon $(1997,313)$, the dissolution of carbonate rock is most effective below sediment. Song Linhua $(1986,9)$ emphasizes the importance of the recurring corrosion capability of water where water percolating through the soil mixes with saturated water flowing along the contact of the rock and soil. He also established that the rate of occurrence of forests is ten times higher in areas with organic substances in the soil than that occurring at the tops of the hills (Song 1986, 9). Zhang $(1997,79)$ determined that corrosion notches and niches form below the sediment. The frequent distinct bends in subsoil channels and large longitudinal subsoil notches lead to the conclusion that the contact 
with the rock is often less permeable and that corrosion is distinctly more effective at the level of the soil. Smaller meandering channels are often found below subsoil channels that are wider in the upper part and longitudinal notches. Of course, the size of subsoil rock forms is also influenced by the amount of the sediment in the cracks between pillars and the time of their formation. The largest channels develop when the level of the sediment lowers slowly and evenly.

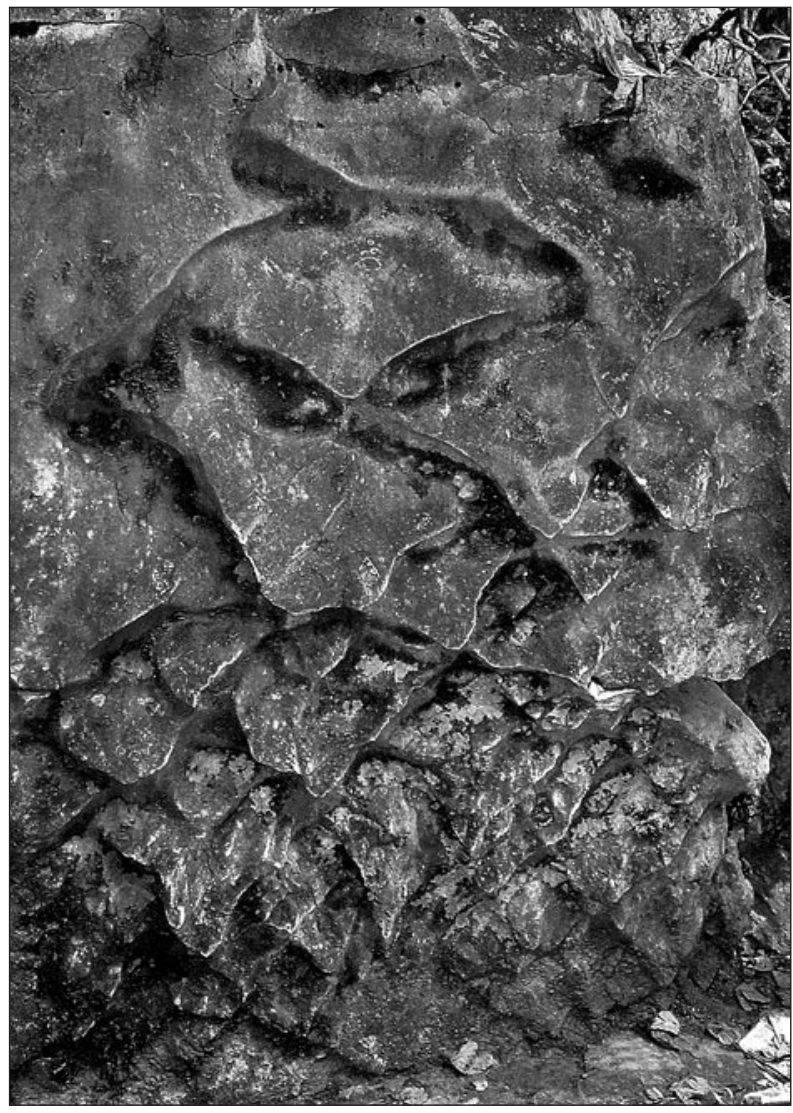

Fig. 5: Subsoil scallops. (Photo: T. Slabe)

The rock forms whose origin is related to the finegrained sediment and soil that entirely or partially covered the pillars at the time of their origin are divided into those that formed deep below the ground, i.e., pure subsoil forms, those that formed below a thinner layer of soil and vegetation, and composite forms that developed along the surface of the soil and were directly co-shaped by rainwater. Old subsoil rock forms transformed by creeping water are also preserved higher up above the ground. It is also necessary to distinguish between subsoil dissection of the rock that is specifically the result of the composition, fissuring, and stratification of the rock, i.e., weak spots in the rock, and subsoil rock forms shaped by characteristic factors. Due to the relatively even dissolving of rock below soil and sediment, the rock is rounded and the same applies for subsoil rock forms; to the naked eye, the surface of the rock is relatively smooth or characteristically rough on diversely composed or precrystallized carbonates. Large magnification, however, reveals that below-sediment rock surfaces as a rule are slightly rough due to the even corrosion of grained rock (Slabe 1994).

Subsoil channels (Fig. 2. 1) occur due to the continuous flowing of water along the contact with soil. The largest typically occur when the water flows behind a vertical or steep contact. The diameter of the large and as a rule vertical and single channels measures from 20 $\mathrm{cm}$ to one meter and more. Along the fissures where channels are most frequently found, they are deeper, and subsoil shafts can form along the most distinct channels. The size of the diameter can vary within the same channel. Deeper below the soil and sediment, large channels are often narrower. The rock therefore dissolves the fastest beside the upper section of the soil and sediment. Song $(1986,9)$ explains the widenings in subsoil channels by the mixing of water creeping along the contact with water permeating through the soil. Smaller subsoil channels 5 to $20 \mathrm{~cm}$ in diameter crisscross the wall at different angles and are often meandering. Their width is even over their entire length or wider at the contact with other channels. They can be connected in a network. The smallest channels that only reach $5 \mathrm{~cm}$ in diameter usually meander the most. Their formation is also more distinctly influenced by the composition and fissuring of the rock on which they form.

Subsoil channels occur mostly through the moistening of the soil and sediment at a permeable contact with the rock and less through distinct smaller currents. Their shape and frequent dissection by horizontal notches reflect this. Smaller tubes up to $1 \mathrm{~cm}$ in diameter often form at the bottom of channels between rock and clay and water flows through them. The dissolving of rock at the contact with moist soil is more distinct and continues longer. Along with the properties of the rock, the permeability of the contact with the soil and the amount of water flowing at the contact largely dictate the size and shape of the channels. It appears that smaller and more meandering channels form along less permeable contacts. The type of contact between the wall and the soil can be different in places or liable to change. The walls of larger channels can therefore display meandering flutes. Along less permeable contacts subsoil channels are larger at the level of the sediment and soil and narrow quickly below it. Gams (1997) determined the relationship between the growth of subsoil caves and the permeability of the material filling them. In the upper part immediately below the surface, such channels display mostly 
distinctly funnel-shaped mouths whose diameters can exceed one meter.

Channels with semi-circular bottoms also occur on more or less gently inclined rock covered by soil (Sweeting 1972, 93; Perna \& Sauro, 1978; Trudgill 1985, 57). They form as the consequence of water permeating through the soil and converging. On steep surfaces they can be parallel (Williams 1966, 164) and we can talk about subsoil flutes because the water permeating through the soil flows evenly across the entire surface. On gently inclined rock surfaces, however, they are connected into a "branched" network. Unique channels with omega-shaped or semi-circular cross sections form at the bottom of cracks between rock pillars or teeth where fissures wedge out.

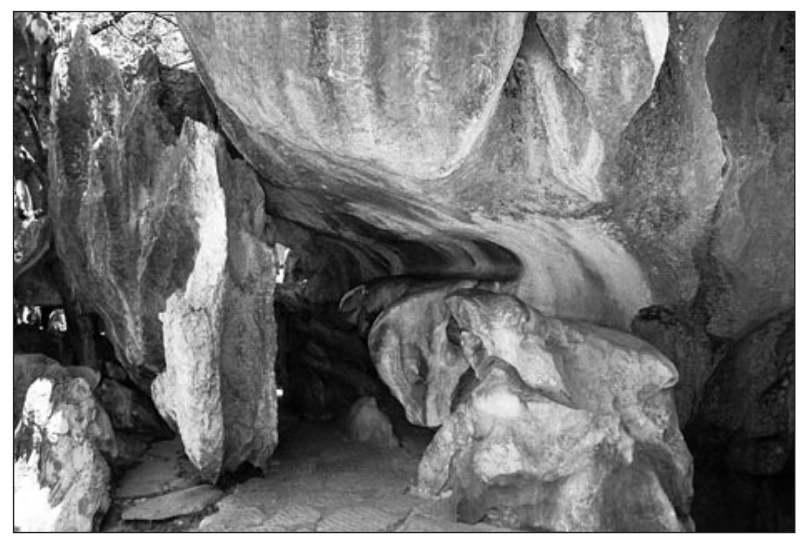

Fig. 6: Subsoil notches. (Photo: T. Slabe)

A special type of channel (Sweeting 1972, 89) forms when channels are filled with soil or their bottoms are covered and the rock around them is denuded. In most cases they take the characteristic shape of the Greek omega letter turned upside down. They can occur in several stories. Due to the lowering of its level, soil remained only at the bottoms of the channels, which consequently deepened and widened. Channels also lead from subsoil cups where water converged. Often they developed from subsoil tubes that became uncovered when the upper layer of rock disintegrated. The latter start transforming into channels from the moment the level of the soil surrounding the pillars drops below the level of the tubes.

Subsoil scallops (Figs. 2. 2, 5) occur due to water flowing along a longitudinally permeable contact of rock with soil. They are subsoil recesses joined in a network. Their diameters measure between 15 and $50 \mathrm{~cm}$. They are shallow and in most cases slightly deeper on the upper side. They are typically found on overhanging rock surfaces. On distinctly overhanging surfaces they can be arranged like fish scales one above the other. The narrower lower parts protrude from the walls.

Below the ground the circumferences of subsoil notches are often dissected by subsoil scallops. In places, channels lead to the subsoil scallops. As a rule, subsoil scallops do not occur along distinct fissures crisscrossing walls or along bedding planes where semicircular channels develop instead.

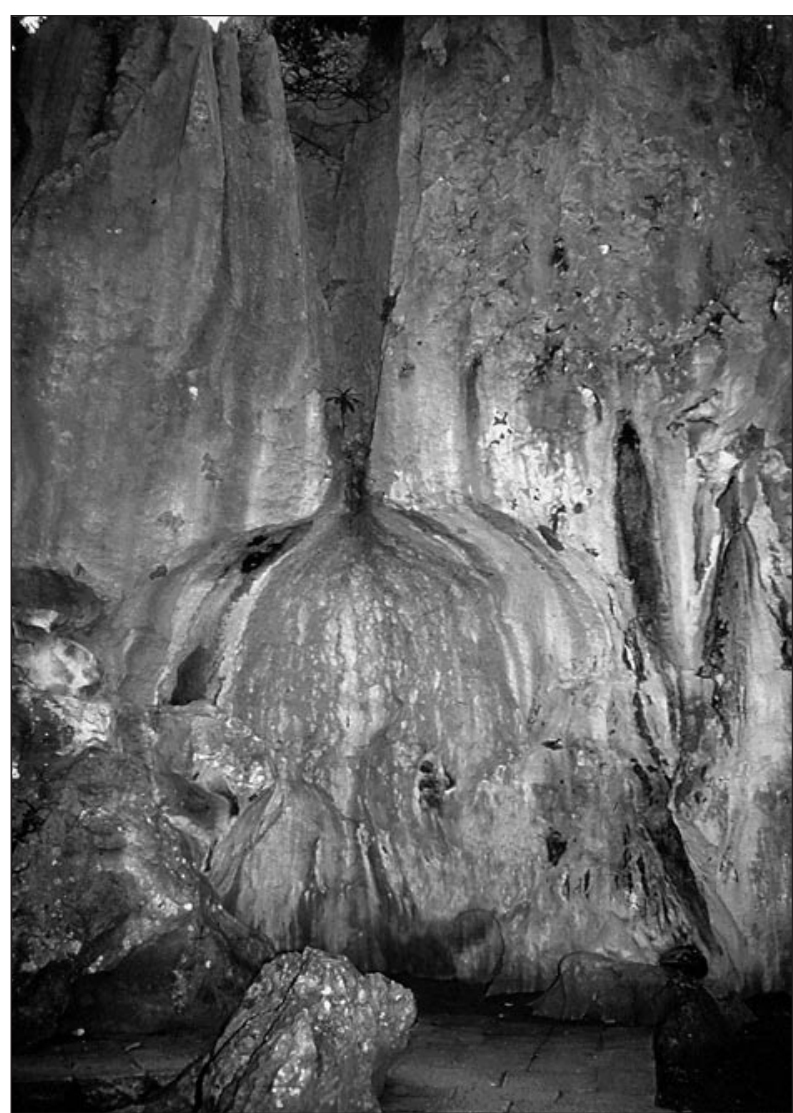

Fig. 7: Subsoil half-bells. (Photo: T. Slabe)

Subsoil notches (Figs. 2. 3, 6) occur due to the corrosion of the rock along a long-term level of sediment or soil surrounding it. The water flows to the contact over a large surface, corroding the contact more or less distinctly, and then flows between the rock and the soil. Smaller subsoil notches, 10 to $20 \mathrm{~cm}$ in diameter, have the shape of semi-circular horizontal channels most often with sharper upper edges and rounded lower edges. Larger subsoil notches indent one meter or more into the rock and are up to one meter high (Waltham 1984, 182; Ford et al. 1997; Jennings 1973, 48; Ollier 1984, 46). Their lower parts are undercut. The rock was subject to more rapid long-term dissolving below the moist ground that made it rounded and smooth. The lower plane of the notch is horizontal and the semi-circular 
upper plane tilts toward the lower one. The upper part of the notch is transformed due to water creeping down the rock. The notches can be observed at different heights of relatively quickly and intermittently denuded rocks. The water that shapes them often flows between the rock and the soil below them and forms subsoil channels or scallops.

The forms described can be distinguished from notches that occur due to frequent more rapid dissolving of rock along horizontal bedding planes. The latter are typically narrower and most often comparatively deep relative to the diameter of the opening.

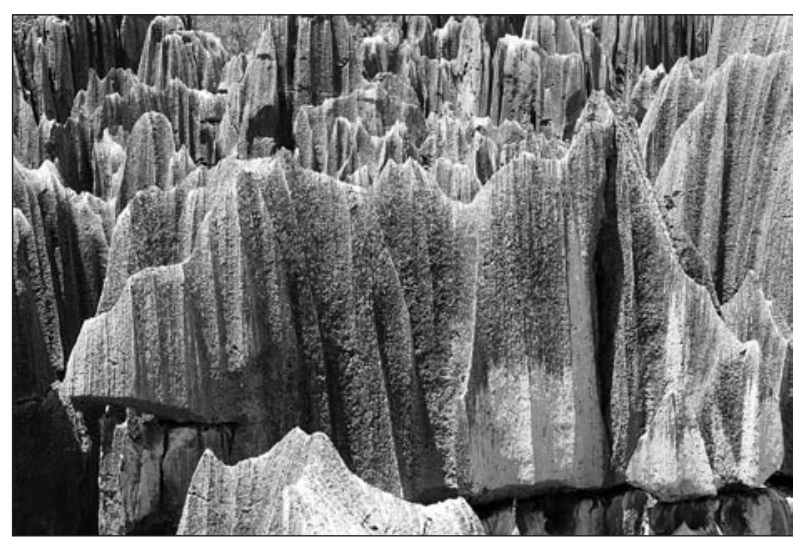

Fig. 8: Flutes and channels. (Photo: T. Slabe)

Subsoil half-bells (Figs. 2. 4, 7) occur below channels that continuously feed large volumes of water to the sediment or soil surrounding the rock. The contact is not permeable enough to drain away the amount of the water that reaches it. Subsoil half-bells measure up to three meters in diameter. Above soil or sediment they have a characteristic bell or half-bell shape. Their shape and size is related to the amount of water flowing to the soil, the permeability of the contact between the rock and soil or sediment, and the speed at which the level of soil or sediment drops. The inflow channel can take the shape of a tube when forming along a distinct fissure. Deeper below the ground, the bell-like widening often narrows gradually into a subsoil channel.

Subsoil cups (Fig. 2. 5) occur on horizontal surfaces under a thinner layer of porous soil that covers the rock entirely or only in places. The diameter of smaller cups is between one and five centimeters while the diameter of larger cups can reach several decimeters. They occur due to the percolation of the water through the soil to the rock and typically form at weak spots in the rock. The water keeps the soil in the pockets moist and as a rule enlarges and rounds them outward when the rock is surrounded by fine-grained sediment or soil. Their cross sections are therefore round, or elliptical along fissures.
Cups are most often found side by side or already connected to each other. Subsoil holes or small cavities can develop from subsoil cups, especially on fissured or porous rock.

Solution pans can also develop from subsoil cups found on horizontal surfaces if the rock is denuded. Their development is presented by Gams $(1971,33)$, who calls this type of subsoil cup a "covered solution pan."

Special subsoil cups form below newly forming weathered debris, moss, or lichen that covers the rock in places, keeping it moist and accelerating the corrosion of the rock. Cups are originally shallow with gently sloping walls. Their diameters measure from a few centimeters to several decimeters. Some have channels that drain excess water. On inclined surfaces their upper sections are semi-circular and wide, and they narrow downwards.

Cracks develop with subsoil stone teeth between them where vertical fissures crisscross carbonate rock massifs in various networks. The cracks most often have V-shaped cross sections of various widths and depths. Subsoil channels are frequently found on their bottoms. Densely distributed teeth can only have narrow cracks between them, 0.2 to 0.75 meters wide and mostly up to 2 meters deep. On the surface and below it, such stone teeth are stubby. The teeth are narrow and pointed when the cracks between them are 2 meters wide or more and more than 5 meters deep. In the latter case, only narrow and relatively low points protrude on the surface. The type and composition of the rock are not reflected in the shape of subsoil stone teeth as much as they are on the same rock at the surface where they determine the shape of the pillars and to a considerable extent their rock relief. Subsoil stone teeth are namely most usually conical and rounded. Such cases are also found in the Naigu (Knez \& Slabe 2001) and Lao Hei Gin (Knez \& Slabe 2006) stone forests. They display semi-circular subsoil rock forms as well as fissures or bedding planes along which semi-circular notches form. Water therefore reaches and shapes subsoil teeth quite evenly.

Water that flows down the contact of rock and soil or permeates through the soil to the rock collects in cups that developed at weak spots in the rock and then flows downward over the stone teeth. Subsoil channels develop at the bottoms of cracks between the teeth, they can cut the tops of stone teeth (Fig. 2. 6), or they can form as runoff channels from subsoil cups. Channels can be developed in several stories. Due to the lowering of its level, the soil was only preserved at the bottoms of the channels and consequently deepened and widened them.

Subsoil tubes and anastomoses (Fig. 2. 7), which reach 1.5 meters in diameter, often crisscross pillars in stone forests. In most cases they developed along distinct bedding planes and fissures. Water deposited sediment 
in originally small tubes and thus widened them. They indent deep into the rock and some run through the pillars. In most cases their cross section is the shape of a horizontally elongated ellipse. The bottoms of semi-circular tubes are covered with clay if they are at the level of the sediment and soil. Their ceilings often display abovesediment ceiling channels that developed when the level of the subsoil tubes was below the soil.

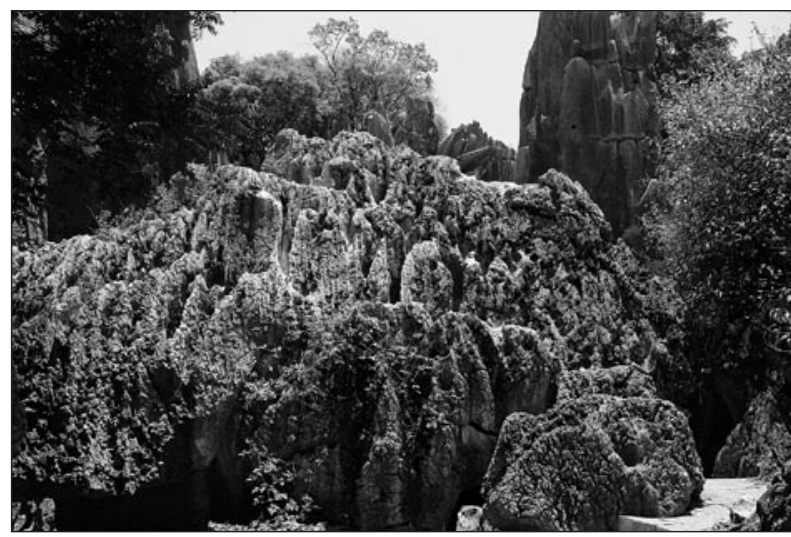

Fig. 9: Rock, etched bellow dense vegetation. (Photo: T. Slabe)

\section{ROCK FORMS CARVED BY RAINWATER}

On relatively pure and thickly stratified limestone with a relatively even composition and not heavily fissured or dolomitized, rainwater creates distinct rock forms. Rock relief shaped by rainwater on the upper five meters of the pillars is the most distinct and diverse, and traces of water creeping down the vertical and slightly slanted walls reach all the way to the feet of the pillars. Kogovšek $(1998,68)$ determined the importance of various types of rain that influence the rate of dissolving of the pillars due to differences in the thickness of the film of water.

The first subgroup of rock forms directly or indirectly shaped by rainwater includes flutes and channels. The upper sections of pillars display flutes ("rillenkarren”; Bögli 1981; Sweeting 1995; Chen et al. 1983). Flutes (Figs. 2. 8, 8) are one to three centimeters wide and several tens of centimeters long. The more evenly fine-grained the rock is, the more the flutes have regular forms and the more level the ridges between them are. Meandering ridges and the dissection of flutes into cups that are characteristic particularly of flutes on steeply inclined surfaces (Slabe 1995) are the consequence of the composition and precrystallization of the rock. Flutes are found on both very inclined and gently sloping surfaces. Glew and Ford $(1980,27)$ established that they develop on surfaces inclined from $12^{\circ}$ to $70^{\circ}$. On gently sloping surfaces they are similar to one another, while on steeper rock surfaces they merge into larger mostly shallow channels that are therefore distinctly ribbed in their upper parts. On steep conical pillars there are on the ridges therefore only shallow and less distinct flutes that dissect larger channels. On wider pillar tops, water flows from the flutes that dissect the ridges of the tops into shallow, wider, and gently sloping channels. Flutes develop when the film of water is still thin and does not prevent the direct contact of rain drops with the soluble rock. However, once the film is thick enough, a flat surface (Glew \& Ford 1980, 25) or the channels described above, a characteristic form below flutes (Slabe 2005), develop. Forti $(1977,10)$ identified flutes of various sizes on different rock. The most regular forms appear on micrite (Forti 1997, 11).

Individual channels (Figs. 2. 9, 8), usually up to $50 \mathrm{~cm}$ in diameter, have various origins. Channels with diameters up to $15 \mathrm{~cm}$ are characteristic of the steep and vertical upper sections of pillars. Flutes merge in them. Often these channels are dissected only by less distinct longitudinal ridges. On the tops they often have open funnel-like forms that have gently sloping walls covered with flutes and with channels on the steeper walls below them. At this stage it is believed that the funnels are the legacy of subsoil channels. Stone teeth are most often indented by semi-circular subsoil channels that are wider at the top. Channels also develop due to water flowing from the only slightly inclined and shallow channels described above that developed on the wider tops of pillars below the flutes. On the tops of blocky pillars there were frequent subsoil cups, but solution pans dominated after rapid denudation. Channels developed due to water flowing from both. Channels with diameters of 1 to 50 $\mathrm{cm}$ also developed as the wall of a deepening solution pan or subsoil cup. According to Habič (1980), deep channels with sharp edges, which are also found on fallen pillars, occur in more humid climates with heavy downpours.

The second subgroup of rock forms carved by rainwater creeping down the walls of pillars includes a variety of scallops found on vertical and overhanging walls and if the rock is unevenly composed or fissured also on horizontal surfaces and small pendants on overhangs. These forms also appear on cave walls (Slabe 1995). They occur due to the manner water creeps down rough or fissured rock. Researchers (Sweeting 1995; Chen et al. 1983) who described scallops divide them into small with diameters of only $1 \mathrm{~cm}$, medium with diameters of 5 to $15 \mathrm{~cm}$, and large with diameters reaching $30 \mathrm{~cm}$. Their size presumably reflects the velocity of the water flowing down the rock and its hydraulic properties (Sweeting 1995).

Relative to their size, scallops are divided into those that are 0.5 to $5 \mathrm{~cm}$ in diameter and those whose diameters most often measure between 5 and $10 \mathrm{~cm}$. 
Their division according to the manner of their formation and shaping reveals more about them. This type of scallop develops due to water creeping down rough and variously inclined rock surfaces. Their origin, particularly of the smallest forms, is therefore defined by the relatively uniform fine-grained composition of the rock on which creeping water eddies over a rough surface. Flutes on vertical walls are dissected by short scallops of the same width. Their edges are therefore jagged. Scallops also appear on the walls of vertical channels and are linked in columns that reflect a smaller amount of water creeping down vertical rock. They display a similar distribution on ridges of pillars. In the narrow cracks between pillars on concave sections of the rock, scallops can be obliquely elongated and $1 \mathrm{~cm}$ wide and $3 \mathrm{~cm}$ long, which indicates a strong breeze that influences the direction of the creeping water. On overhanging walls there are scallops that are deeper on the inflow side and connected in a network. Most of them are $0.5 \mathrm{~cm}$ long and $1 \mathrm{~cm}$ wide. They are relatively deep and have distinct edges. Below the channels on overhangs where larger amounts of water flow faster, there are scallops with diameters up to $1 \mathrm{~cm}$, while on the surrounding equally overhanging surfaces their diameters are larger, measuring between 3 and $5 \mathrm{~cm}$. On the ceiling the scallops transform into small pendants. Their cross sections are usually triangular with rounded tops. They form due to the uneven dissolving of the grained rock below a thin layer of water that flows over the ceiling. The water collects on pieces of rock protruding from the ceiling and because its corrosion effect is diminished the difference between the pendants and the cups between them increases (Slabe 1995, 79). Characteristic cups develop along tiny vertical fissures, mostly with teardrop shapes (Slabe 1995, 97).

The walls above horizontal bedding planes are also dissected in characteristic half-pocket-like manner. The pockets measure from 3 to $20 \mathrm{~cm}$ in diameter. Smaller ones are semi-circular while larger ones have flat circular bottoms on the upper layer of the lower stratum.

The formation of scallops is dictated in particular by the grainy composition, fissuring, and stratification of the rock, and their size and shape is determined by the amount of water creeping at different rates across variously inclined rock surfaces. On vertical and inclined rock surfaces, smaller amounts of water merge into trickles, on overhanging surfaces scallops develop due to the characteristic gravitational flow of water, and pendants form on ceilings. Research so far has not indicated that the size of scallops is only the trace of the speed of water flowing over rough rock (Sweeting 1995, 127) or that large scallops are simply a version of smaller ones as in caves (Slabe 1995).
Various solution pans are also found on the pillars. Their diameters range from one centimeter to a meter or more as their depth can as well. The smallest solution pans with diameters up to $10 \mathrm{~cm}$ are most often semi-circular in shape and their bottoms are usually flat. They often lie side by side with thin edges between them. The largest solution pans formed along fissures between pillars.

Solution pans are often most distinct at the tops of lower, formerly overgrown pillars that were recently denuded. Subsoil cups therefore in most cases evolved into solution pans. The development from subsoil cups into solution pans was also identified by Gams $(1972,32)$ and Zhang $(1997,79)$. Solution pans on various types of rock were described by Forti (1971).

Solution pans and subsoil cups that tend to deepen are often found on the walls of pillars, with channels above them that are their former walls. Such solution pans can also be small, only one centimeter in diameter. They look like bottoms of flutes of various lengths at different heights on the wall.

\section{ROCK SURFACE OF STONE FOREST PILLARS SHAPED BELOW VEGETATION}

Below dense vegetation and a very thin layer of soil or soil only present in patches, the rock is usually corroded into forms determined by the composition, fissuring, and stratification of the rock (Fig. 9). Elongated small notches up to two centimeters wide and in places only slightly deeper indicate the diverse stratification of rock layers and bedding planes. Fine and dense crushed rock is dissected by networks of equally sized small notches. This formation is often true only for the wider tops of lower pillars, their lower parts, and notches along bedding planes, in short, areas that have been overgrown. The same rock is smooth or dissected by rounded small cups if it was shaped below the ground.

Under vegetation the rock surface is usually dissected by 1-mm cups. A large proportion of the pillars is covered by lichen and moss and the rock surface is finely corroded (Slabe 1995). Moses and Viles (1996) determined the importance of the biological creation of nanomorphology but although cups form below lichen, rain is still the decisive factor in shaping the rock. Fiol, Fornós and Ginés (1996) draw attention to the great importance of the mechanical removal of larger fragments of rock isolated by biocorrosion under algae that covers flutes. Biocorrosion also accelerates the development of solution pans. 


\section{CONCLUSION}

Geologic studies of the rock in the Major stone forest have established that the type of rock is clearly reflected in the intensity of corrosion and erosion and with it in the formation and morphological appearance of individual stone pillars and larger blocks of rock.

Even composition and thick stratification of the rock enables entire development of forms, which show the way of shaping of this type of stone forests. Their morphology is precisely and complexly described for the first time. It is the base for further study of stone forests shaping and developing on different rock and in different geomorphological and hydrological conditions.

The rock relief on the pillars in stone forests reveals the interwoven traces of the original shaping of the rock below soil and sediment, of the lowering of the level of soil and sediment, and of the younger but distinct transformation of pillars by rainwater, which naturally dominates on the tops.

Subsoil rock forms can be divided into three types. The first develops below sediment and soil, the second below a thin layer of porous soil that covers the rock in places, and the third at the level of sediment and soil. Water flowing along the contact of soil and rock causes the formation of larger and straight as well as smaller and meandering subsoil channels. Subsoil scallops on vertical or overhanging walls form when the rock is surrounded by porous sediment and the contact between them is more permeable. The frequent narrowing of overhanging pillars below the top is a trace of the more rapid dissolving of carbonate rock below soil and sediment. Longitudinal subsoil wall notches and half-bells form at long-lasting levels of soil and sediment. Subsoil cups and channels form under a thin layer of soil due to the percolation of water through it. Subsoil tubes of various sizes develop through pillars along fissures or bedding planes under the ground. Distinct subsoil rock forms indicate the efficient dissolving of carbonate rock under the ground.

Flutes are typically found on sharp tops in funnellike notches that developed from former below-sediment channels. On steep walls the flutes merge into channels. Channels also form below funnel-like notches and where water flows from subsoil cups and solution pans. Vertical and overhanging walls are also dissected by a variety of scallops carved by rainwater and on the most overhanging parts by small pendants. Solution pans are found on gently sloping sections. The gradual transformation of the rock relief is also indicated by composite forms, originally subsoil channels whose upper parts were reshaped by rainwater. The contact at a long-lasting level of soil and sediment is bell-shaped and the wall overhangs.
The fact that the pillars were overgrown is most visible on wider tops, on gently sloping walls, and immediately above the ground. A rock surface that was overgrown is characteristically finely corroded.

Below the ground, fissured carbonate rock is shaped into subsoil karren, where stone teeth and smaller pillars with characteristic rock relief featuring subsoil rock forms are found between cracks. Subsoil channels with semi-circular or omega-shaped cross sections and subsoil scallops first form below the soil and sediment. These forms can also crisscross the tops of subsoil stone teeth. With the lowering of the ground level, which is usually the result of the development of the underground water network below the stone forest, protrusions appear on the surface where they are transformed by rainwater. The rounded channels and cracks that cut the tops of stone teeth start to transform into sharp funnel-like notches with flutes on them. As the sediment and soil level lowers, the transformation continues downwards. Rock forms carved by rainwater are originally defined by subsoil rock forms.

Rock relief reveals the manner of the stone forest's formation and presents the traces of its development. Rock forms that formed at the level of the ground bear witness to temporary but long-lasting ground levels. This type of rock form that remains on the walls of the pillars reveals periods when the ground level dropped quickly. Particular attention must be given to human activity in the stone forests, especially those arranged for tourist visits where cracks between pillars are often deepened in many places and subsoil rock forms are denuded. It was also linked the rock relief of the pillars with the rock relief in the caves located below the forest. They too contain characteristic traces of distinct changes in their conductivity. Signs of rapid streams of water through the passages alternate with the filling of caves with gravel or fine-grained alluvium above which above-sediment channels formed. In certain periods the flow of water through caves was small. It can be therefore concluded that water also flowed occasionally on the surface between the stone pillars and the sediment level remained unchanged for longer periods. The water table below the forest is mostly close to the surface and therefore younger factors could quickly cover the traces of older factors in the caves. This kind of comparison and analysis of rock relief to trace the development of stone forests will require further in-depth studies including a more detailed comparison of the level of characteristic cave and surface rock forms and comparison with other development indicators such as various sediments. 


\section{ACKNOWLEDGEMENT}

Research was supported by Yunnan Stone Forest Scenic Area Authority Bureau within the projects Development of Stone Forest - lithology, selective karstification and its rocky relief and The caves in shilin as traces of its evolution. It was included in UNESCO IGCP project No. 598.

\section{REFERENCES}

Bögli, A., 1960: Kalklösung und Karrenbildung.- Zeitschrift für Geomorphologie, Supp. 2, 5-21.

Bögli, A., 1981: Solution of limestone and karren formation.- In: Sweeting, M.M. (ed.) Karst geomorphology. Hutchinson Ross Publishing Company Benchmark Papers in Geology 59, pp. 64-89, London.

Chen, Z.P., Song, L.H. \& M.M. Sweeting, 1986: The Pinacle Karst of the Stone Forest, Lunan, Yunnan, China: an example of sub-jacent karst.- In: Paterson K. \& M.M. Sweeting (eds.) New Direction in Karst. Geo books, pp. 597-607, Norwich.

Dzulynski, S., Gil, E. \& J. Rudnicki, 1988: Experiments on kluftkarren and related lapis forms.- Zeitschrift für Geomorphologie 32, 1, 1-16.

Fabre, G. \& J. Nicod, 1982: Lapiés, modalités et rôle de la corrosion, crypto-karstique.- Phénomèn karstique III, Mémoires et documents de géographie, 115-131.

Fiol, L., Fornós, J. \& A. Ginés, 1996: Effects of biokarstic processes on the development of solutional rillenkarren in limestone rocks.- Earth Surface Processes and Landforms, 21, 5, 447-452.

Ford, D. \& P. Williams, 1989: Karst Geomorphology and Hidrology.- U. Hyman, pp. 601, London.

Ford, D., Salomon, J.N. \& P. Williams, 1997: The Lunan Stone forest as a potential world heritage site.- In: Song, L. et al. (eds.) Stone Forest, a Treasure of $\mathrm{Na}$ tural Heritage. China Environmental Science Press, pp. 107-123, Beijing.

Forti, F., 1972: Le »vaschette di corrosione«. Raporti tra geomorfologia carsica e condizioni geolitologiche delle carbonatiti affioranti sul carso triestino.- Atti e memorie, 11, 37-66.

Forti, F., 1977: Studio geomorfologico delle scannellature carsice (rillenkaren) sulle rocce carbonatiche calcaree del carso triestino.- Mondo sotterraneo, 1, 8-14.

Gams, I., 1971: Podtalne kraške oblike.- Geografski vesti, 43, 27-45.

Gams, I., 1997: Climatic and lithological influence on the cave depth development.- Acta carsologica, 26, 2, 321-336.
Ginés, A., 1990: Utilización de las morfologías de lapiaz como geoindicadones ecológicas en la Serra de Tramuntana (Malorca).- Endins, 16, 27-39.

Ginés, A., 1996: An environmental approach to the typology of karren landform assemblages in a Mediterranean mid-mountain karst: the Serra de Tramuntana, Mallorca, Spain.- In: Fornós, J.J. \& A. Ginés (eds.) Karren landforms, pp. 163-176, Palma de Mallorca.

Glew, J. R. \& D. C. Ford, 1980: A simulation study of the development of rillenkarren.- Earth Surface Processes, 5, 1, 25-36.

Habič, P., 1980: S poti po kitajskem krasu. Summary: From the way to the Chinese karst.- Geografski vestnik, 52, 107-122.

Jakucs, L., 1977: Morphogenetics of karst regions.Akadémiai Kiadó, pp. 284, Budapest.

Jennings, J.N., 1973: Karst.- M.I.T. Press, pp. 253, Cambridge, Massachusetts, London.

Knez, M., 1996: Vpliv lezik na razvoj kraških jam. (Primer Velike doline, Škocjanske jame).- Založba ZRC, pp. 186, Ljubljana.

Knez, M., 1997: Prvi rezultati raziskav kamnine v treh lunanskih kamnitih gozdovih (Yunnan, Kitajska).Acta Carsologica, 26, 2, 431-439.

Knez, M., 1998: The influence of bedding-planes on the development of karst caves (a study of Velika Dolina at Škocjanske jame Caves, Slovenia).- Carbonates and evaporites, 13,2, 121-131.

Knez, M. \& T. Slabe, 2001a: Oblika in skalni relief stebrov v Naigu kamnitem gozdu (JZ Kitajska).- Acta carsologica, 30, 1, 13-24.

Knez, M. \& T. Slabe, 2001b: The Lithology, Shape and Rock Relief of the Pillars in the Pu Chao Chun Stone Forest (Lunan Stone Forests, NW China).Acta carsologica 30, 2, 129-139.

Knez, M. \& T. Slabe, 2002: Lithological and morphological properties and rock relief of the Lunan stone forests.- In: Gabrovšek, F. (ed.) Evolution of Karst: From Prekarst to Cessation. Založba ZRC, pp. 259266, Ljubljana. 
Knez, M. \& T. Slabe, 2006: Lithological and Morphological Characteristics and Rock Relief of the Lao Hei Gin Shilin- Stone Forest (Lunan, SW China).- Acta carsologica, 35, 1, 99-104.

Knez, M., Liu, H. \& T. Slabe, 2011: SouthChina Karst 2.Založba ZRC, pp. 237, Ljubljana.

Kogovšek, J., 1998: Rock dissolution in stone forests.- In: Chen, X., F. Gabrovšek, C. Huang, Y. Jin, M. Knez, J. Kogovšek, H. Liu, A. Mihevc, B. Otoničar, M. Petrič, M. Shi, T. Slabe, S. Šebela, W. Wu, S. Zhang \& N. Zupan Hajna (eds.) South China Karst 1. Založba ZRC, pp. 247, Ljubljana,

Lin, J., 1997: Genesis of Lunan Stone Forest and its Geomorphological Significance.- In: Song, L. et al. (eds.) Stone Forest, a Treasure of Natural Heritage. ChinaEnvironmental Science Press, pp. 30-33, Beijing.

Maire, R., Zhang, S. \& S. Song, 1991: Genese des karsts subtropicaux de Chine du sud (Guizhou, sichuan, Hubei).- Gebihe 89, Grottes et karsts tropicaux de Chine Meridionale, Karstologia memoires, 4, 162186.

Moses, C.A. \& H.A. Viles, 1996: Nanoscale morphologies and their role in the development of karren. In: Fornós, J. J. \& A. Ginés (eds.) Karren Landforms. Universitat de les Illes Balears, pp. 85-96, Palma de Mallorca.

Nicod, J., 1976: Corrosion de type crypto-karstique dans les karst mediterranneens.- Karst Processes and Relevant Landforms, 171-179.

Ollier, C., 1984: Weathering.- Longman, pp. 270, London, New York.

Perna, G. \& U. Sauro, 1978: Atlante delle microforme di dissoluzione carsica superficiale del Trentino e del Veneto.- Memoire del Museo Tridentino di Scienze naturali, 22, 189-199.

Salomon, J.-N., 1997: Comparaison entre les "Stone forests" du Lunan (Yunnan-Chine) et les Karsts a "Tsingy" de Madagascar.- In: Song, L. et al. (eds.) Stone Forest, a Treasure of Natural Heritage. China Environmental Science Press, pp. 124-136, Beijing.

Sauro, U., 1976: The Geomorphological Mapping of »Karrenfelder« Using very Large Scales: an Example.- Karst Processes and Relevant Landforms, 189-199.

Slabe, T., 1992: Naravni in poskusni obnaplavinski jamski skalni relief. [Natural and experimental cave rocky relief on the contact of water and sediments].- Acta carsologica, 21, 7-34.
Slabe, T. 1996: Karst features in the motorway section between Čebulovica and Dane.- Acta carsologica, 13, 221-240.

Slabe, T., 1994: Dejavniki oblikovanja jamske skalne površine.- Acta carsologica, 23, 369-398.

Slabe, T., 1995: Cave Rocky Relief and its Speleogenetical Significance.- Založba ZRC, pp. 128, Ljubljana.

Slabe, T., 1999: Subcutaneous rock forms.- Acta carsologica, 28, 2, 255-271.

Slabe, T., 2005: Two experimental modelings of karst rock relief in plaster: subcutaneous "rock teeth" and "rock peaks" exposed to rain.- Zeitschrift für Geomorphologie 49, 1, 107-119.

Song, L.H., 1986: Origination of stone forest in China.International Journal of Speleology, 15, 1-4, 3-33.

Sweeting, M.M., 1972: Karst landforms.- Macmillan, pp. 362, London.

Sweeting, M.M., 1995: Karst in China.- Springer-Verlag, pp. 265, Berlin, Heidelberg, New York.

Trudgill, S.T., 1985: Limestone Geomorphology.- Longman, pp.196, London, New York.

Trudgill, S.T., 1986: Limestone weathering under a soil cover and the evolution of limestone pavements, Malham district, north Yorkshire, UK.- In: Paterson K. \& M.M. Sweeting (eds.) New direction in Karst. Geo books, pp. 461-471, Norwich.

Yuan, D., 1991: Karst of China.- Geological Publishing House, pp. 224, Beijing.

Waltham, A.C., 1984: Some features of karst geomorphology in south China.- Cave science, The Transaction of the British Cave Research Association, 11, 185-199.

Williams, W.P., 1966: Limestone pavements with special reference to Western Ireland.- Institute of British Geographers Trasnsaction, 40, 155-172.

White, W.B., 1988: Geomorphology and Hydrology of Karst Terrains.- Oxford University Press, pp. 464, New York.

Yu, J. \& B. Yang, 1997: Definition of Shilin and its Evolution in Lunan County, Yunnan, China.- In: Song, L. et al. (eds.) Stone Forest, a Treasure of Natural Heritage. China Environmental Science Press, pp. 63-67, Beijing.

Zhang, S., 1997: Stone forest in China and pinnacle karst in Madagascar.- In: Song, L. et al. (eds.) Stone Forest, a Treasure of Natural Heritage. China Environmental Science Press, pp. 78-80, Beijing. 